\title{
PRETERM PRE LABOUR RUPTURE OF MEMBRANES;
} EFFECT OF CONSERVATIVE MANAGEMENT ON FETO MATERNAL OUTCOME

\author{
Dr. Saadia Yasir, Dr. Bushra Kant, Dr. Tahira Jabbar
}

ABSTRACT... Study Objective: The objective of this study is to describe the maternal and perinatal outcome of conservative management in PPROM. Design: Descriptive prospective study. Period: One year from August 2006 to August 2007. Setting: Maternal and child health (MCH) Centre PIMS Islamabad. Material and Methods: 50 patients between 28-36 weeks of gestation presenting with PPROM. Results: The mean age was $27+5.1$ years, $14(28 \%)$ were having gestational age between 28to 32 weeks and $36(72 \%)$ were between 33 to 36 weeks of gestation. $34(68.0 \%)$ of the mothers had no history of abortions while $10(20.0 \%)$ had $1-2$ abortions and $6(12.0 \%)$ had 3 or more abortions. Sixteen (32.0\%) women had previous PRROM while $10(20.0 \%)$ had previous history of preterm labor. Inverse correlation was observed between latency period and gestational age. Among 14(28\%) women with gestational ages between 28 to 32 weeks 10 delivered within 48 hours and 4 after 48 hours. Among 36(72\%) women with gestational ages between 33-36 weeks 31(62\%) delivered in less than 48 hours and $5(10 \%)$ women delivered after 48 hours.14(28\%) of the 50 babies were admitted in NICU with septicemia, $7(14.0 \%$ ) with RDS, hypoglycemia in 2(4.0\%) and necrotizing enterocolitis in 3(6.0\%). 3 neonates died from septicemia and 2 from RDS. On first follow-up 34.0\% mothers had infections and 8.0\% had post-partum hemorrhage. Conclusions: Expectant management till 36 weeks is a suitable option as gestational age at delivery and birth weight both affect neonatal survival and offer time to administer corticosteroids to allow foetal lung maturity. Foetal deaths occurred due to septicaemia and RDS with direction co-relationship with low birth weight.

Key words: Preterm premature rupture of membrane, latency period, low birth weight

Article Citation

Yasir S, Kant B, Jabbar T. Preterm Pre Labour Rupture Of Membranes; Effect of conservative management on feto maternal outcome. Professional Med J 20(5): 765-771.

\section{INTRODUCTION}

Premature rupture of membranes (PROM) refers to membrane rupture before the onset of uterine contractions; preterm PROM (PPROM) is defined when the pregnancy is less than 37 weeks of gestation. PPROM occurs in $3 \%$ of pregnancies and is responsible for approximately one-third of preterm births ${ }^{1}$. PPROM in a previous pregnancy, genital tract infection, antepartum bleeding, and cigarette smoking have a strong association with PPROM ${ }^{2,3}$. Initially it was standard practice to induce labour upon presentation, believing that expectant management was associated with a high rate of maternal/ foetal/ neonatal infection and potential serious sequelae afterwards. Subsequently, after two large randomized controlled trials, prolongation of latency period is believed to reduce neonatal complications ${ }^{4,5}$. With this in mind the study was conducted at Pakistan Institute of Medical Sciences (PIMS), Islamabad.

\section{MATERIAL AND METHODS}

This descriptive prospective study was conducted on 50 patients at Maternal and Child health ( $\mathrm{MCH})$ centre PIMS Islamabad over a period of one year from August 2006 to August 2007. Women included in the study had gestation age of 28-36 weeks and not in active labour. Patients were excluded if they had severe preeclampsia, intra-uterine growth retardation, diabetes mellitus, gross foetal anomalies not compatible with life, signs of maternal infection (pulse, temperature, abdominal tenderness, colour and smell of liquor) or anhydramnios.

On admission complete history regarding gravidity and parity was taken; accurate dating of gestational age was done by the last menstrual period in patients who were sure of dates with previous regular cycle of 28-30 days and first trimester scan. Diagnosis of PPROM was established by history, sterile speculum 
examination by looking at the pool of liquor in posterior fornix or liquor coming out of cervix, high vaginal swabs for gram staining and culture and sensitivity were also taken, ultrasonography to assess amniotic fluid index (AFI) was done and patients were hospitalized until delivery. At time of admission maternal pulse, blood pressure, temperature, uterine tenderness, amount and colour of liquor was documented. Foetal heart rate recorded by fetoscope, CTG and biophysical profile (BPP) done. Maternal total leucocyte count (TLC) and C-reactive proteins (CRP) were sent. Conservative management was done till the time spontaneous labour started or there were maternal or foetal indication for delivery e.g. chorioamnionitis or placental abruption. Prophylactic antibiotics e.g. injection cephradine $(500 \mathrm{mg}$ intravenously 8hourly) and injection metronidazole (500 mg intravenously 8hourly) were given for 48 hours. Two doses of corticosteroids (dexamethasone) $12 \mathrm{mg}$ intramuscular 12 hours apart were given to establish foetal lung maturity. Consequent management consisted of 6 hourly monitoring of pulse, temperature, uterine tenderness, colour and smell of liquor, and foetal heart rate along with daily CTG. Ultrasonography for BPP was done twice weekly as was complete blood count and CRP. High vaginal swabs (HVS) were sent for culture and sensitivity weekly. Latency period and mode of delivery was noted as was foetal outcome e.g., APGAR score at one and five minutes after delivery, neonatal weight and gender. Neonates were admitted in neonatal intensive care unit (NICU) were followed for morbidity e.g., respiratory distress syndrome (RDS) and septicaemia. Total days of NICU stay were noted and perinatal mortality if occurred was documented. Mothers were followed 4 weeks post natal.

The data was analysed on SPSS-11. Frequencies and percentages were calculated for categorical variables e.g. gravidity, parity, previous PPROM, mode of delivery and APGAR score less than 7 at 1 and 5 minutes after delivery. Mean and standard deviation was calculated for quantitative date e.g. age, total leucocyte count, pulse and temperature. Chi- square test was applied to analyse relationship between two variables e.g., relationship between gestational age and latency period, gestational age and NICU admission, AFI and NICU admission, neonatal weight and NICU admission and also between neonatal weight and perinatal mortality.

\section{RESULTS}

A total of 68 patients were recruited while 18 were excluded due to incomplete date or other obstetrical reasons thus leaving 50 female participants with PPROM. The mean age of the patients was $27+5.1$ years, $14(28 \%)$ of the participants were having gestational age between 28to 32 weeks and in 36 (72\%) women gestational age was between 33 to36 weeks. In our study $16(32.0 \%)$ mothers were primigravida and $31(62.0 \%)$ multigravida and $3(6 \%)$ were grand multi of the participating women $33(66 \%)$ were having regular follow-up whereas $17(34 \%)$ presented for the first time without any regular followup. $34(68.0 \%)$ of the mothers had no history of abortions while 10 (20.0\%) had 1-2 abortions and 6 $(12.0 \%)$ had 3 or more abortions in their lives. Sixteen (32.0\%) women had previous PRROM while 10 (20.0\%) had previous history of preterm labour and none of them smoked. (Table-l) At time of admission in $36(72 \%)$ women AFI was $>5 \mathrm{~cm}$ and in $14(28 \%)$ women AFI was $\leq 5 \mathrm{~cm}$. Mean AFI was $6.8+2.8 \mathrm{~cm}$.

We observed for the signs and symptoms of chorioamnionitis in all women. Mean pulse was $86.9+5.8$ /minute and only one patient developed a fever of 100Fo , 29 (58\%) had abdominal tenderness and $44(88.0 \%)$ had frank leaking but 6 patients among 50 complained of leaking, on examination no watery vaginal discharge observed. Raised TLC was observed in 11 (22\%) patients and 39 (78\%) patients showed normal TLC. $9(18 \%)$ patients developed positive C-reactive protein and $41(82 \%)$ patients had C-reactive protein value of less than $6 \mathrm{IU} / \mathrm{I}$. Only two 
patients showed positive HVS culture growth and 48 (96\%) showed no such growth.(Table-II)

Latency period was less than 24 hours in 12(24\%) of

\begin{tabular}{|c|c|c|}
\hline \multicolumn{2}{|c|}{ Characteristics $(n=50)$} & Study population \\
\hline \multicolumn{2}{|r|}{ Age (years) } & $27.1 \pm 5.1$ \\
\hline \multicolumn{2}{|c|}{$\begin{array}{l}\text { Gestational age at time of presenting } \\
\text { with PPROM (weeks) }\end{array}$} & $\begin{array}{c}28-32 \text { weeks - } \\
14(28 \%) \\
33-36 \text { weeks - } \\
36(72 \%)\end{array}$ \\
\hline \multicolumn{2}{|l|}{ Gravidity } & $\begin{array}{c}62 \% \text { - Multigravida } \\
32 \% \text { - Primigravida } \\
06 \% \text { - Grandmulti }\end{array}$ \\
\hline $\begin{array}{l}\text { Presence } \\
\text { of risk } \\
\text { factors for } \\
\text { PPROM }\end{array}$ & $\begin{array}{l}\text { a) Previous history of } \\
\text { PPROM } \\
\text { b) Previous abortions } \\
\quad 1-2 \\
\quad 3 \text { or more } \\
\text { c) Previous IUGR } \\
\text { d) Previous preterm } \\
\text { labour } \\
\text { e) Smoking }\end{array}$ & $\begin{array}{c}10(20 \%) \\
6(12 \%) \\
10(20 \%) \\
10(20 \%) \\
-\end{array}$ \\
\hline
\end{tabular}

Table-I. Demographic data of participating patients

\begin{tabular}{|l|c|c|}
\hline \multicolumn{2}{|c|}{ Variables } & Results \\
\hline Pulse (minutes) & Increases & $86.9 \pm 5.8$ \\
\hline Temperature & Normal & $49(98 \%)$ \\
\hline Abdominal Tenderness & Present & $29(58 \%)$ \\
& Absent & $21(42 \%)$ \\
\hline Frank leaking of liqour & Present & $44(88 \%)$ \\
& Absent & $6(12 \%)$ \\
\hline Total leucocyte count (Mean \pm S.D) / mL & $12169.4 \pm$ \\
& & 11800.2 \\
\hline C-Reactive proteins & Increases & $9(18 \%)$ \\
& Normal & $41(82 \%)$ \\
\hline High Vaginal Swab & Positive & $2(4 \%)$ \\
& Negative & $48(96 \%)$ \\
\hline
\end{tabular}

Table-II. Clinical and biochemical parameters at presentation of patients with PPROM the women presenting with PPROM, between 24 to 48 hours in 29(58\%), 6(12\%) delivered within one week and only $3(6 \%)$ women were delivered after 7 days. Inverse correlation was observed between latency period and gestational age. Latency period was longer at earlier gestation. Among 14(28\%) women with gestational ages between 28 to 32 weeks 10 delivered within 48 hours and 4 after 48 hours. Among 36(72\%) women with gestational ages between 33-36 weeks $31(62 \%)$ delivered in less than 48hours and only 5 (10 $\%)$ women delivered after 48hours. 44(88\%) women were delivered vaginally, lower segment caesarean section (C-section) was done in 6(12\%) women and emergency $\mathrm{C}$-section was done in 4 cases due to chorioamnionitis and in 2 due to foetal distress.

Neonatal outcome was accordingly, 50(100.0\%) babies were delivered alive, 28(56.0\%) were males and $22(44.0 \%)$ females. APGAR score at 1 minute was $>7$ in 41 (82\%) babies and in $9(18 \%)$ babies it was $\leq 7$. APGAR score at 5 min was $>7$ in $47(94 \%)$ babies and three (6\%) had APGAR score $\leq 7$ at $5 \mathrm{~min}$. At time of birth neonatal weight was less than $2 \mathrm{~kg}$ in 14 $(28 \%)$ babies, between $2-2.5 \mathrm{~kg}$ in $31(62 \%)$ babies and more than $2.5 \mathrm{~kg}$ in $5(10 \%)$. The mean stay in NICU was $3.8+4.4$ days. Out of $50,14(28 \%)$ babies were admitted in NICU with septicaemia, $7(14.0 \%)$ with RDS, hypoglycaemia in $2(4.0 \%)$ and necrotizing enterocolitis in $3(6.0 \%)$. 3 neonates died from septicaemia and 2 from RDS. (Table-III)

It was also observed that among $14(28 \%)$ women at 28-32 weeks of gestation babies of $12(24 \%)$ were admitted in NICU while babies of only $2(4.0 \%)$ out of $36(72 \%)$ women at $33-36$ weeks of gestation were admitted. There is inverse correlation between AFI and NICU admission. Among 14(28\%) women with AFI $\leq$ $5 \mathrm{~cm}$ babies of $9(18 \%)$ were admitted in NICU. AFI was more than $5 \mathrm{~cm}$ in $36(72 \%)$ women at time of admission but babies of only 5 were admitted in NICU. Among 14 babies with birth weight less than $2 \mathrm{~kg}$ 12(24\%) were admitted in NICU. 2 (4\%) babies out of 
31 were admitted with birth weight 2-2.5kg. No NICU admission in babies with birth weight more than 2.5kg. $4(7.54 \%)$ out of 14 babies died with birth weight less than $2 \mathrm{~kg}$ and one early neonatal death in babies with birth weight 2-2.5kg. No early neonatal death was seen in babies with birth weight more than 2.5kg. (Table-III).

On first follow-up 17 (34.0\%) mothers had infections

\begin{tabular}{|c|c|c|}
\hline \multicolumn{2}{|c|}{ Variables } & Outcome \\
\hline $\begin{array}{l}\text { Neonatal } \\
\text { morbidity }\end{array}$ & $\begin{array}{l}\text { None } \\
\text { Septicemia } \\
\text { Necrotizing } \\
\text { enterocolitis } \\
\text { Respiratory distress } \\
\text { syndrome with } \\
\text { hypoglycemia } \\
\text { Respiratory distress } \\
\text { syndrome with } \\
\text { septicemia }\end{array}$ & $\begin{array}{l}72 \% \\
14 \% \\
6 \% \\
4 \% \\
4 \%\end{array}$ \\
\hline $\begin{array}{l}\text { Admission in } \\
\text { NICU according } \\
\text { to birth weight } \\
\text { of neonates }\end{array}$ & $\begin{array}{l}<2 \mathrm{~kg} \\
2-2.5 \mathrm{~kg} \\
>2.5 \mathrm{~kg}\end{array}$ & $\begin{array}{l}\text { Yes } 24 \% \\
\text { Yes } 4 \% \\
\text { None required } \\
\text { admission }\end{array}$ \\
\hline $\begin{array}{l}\text { APGAR score } \\
\text { at one minute }\end{array}$ & $\begin{array}{l}<7 \\
>7\end{array}$ & $\begin{array}{l}18.0 \% \\
82.0 \%\end{array}$ \\
\hline $\begin{array}{l}\text { APGAR score } \\
\text { at five minutes }\end{array}$ & $\begin{array}{l}<7 \\
>7\end{array}$ & $\begin{array}{c}6.0 \% \\
94.0 \%\end{array}$ \\
\hline $\begin{array}{l}\text { Neonatal } \\
\text { mortality }\end{array}$ & Alive & $\begin{array}{l}10 \% \text { (caused by } \\
\text { septicemia and } \\
\text { respiratory } \\
\text { distress } \\
\text { syndrome) } \\
90 \%\end{array}$ \\
\hline $\begin{array}{l}\text { Mode of } \\
\text { delivery }\end{array}$ & $\begin{array}{l}\text { Vaginal delivery } \\
\text { C-Section }\end{array}$ & $\begin{array}{l}88 \% \\
12 \%\end{array}$ \\
\hline $\begin{array}{l}\text { Maternal } \\
\text { outcome at } \\
\text { follow-up }\end{array}$ & $\begin{array}{l}1^{\text {st }} \text { follow up visit } \\
2^{\text {nd }} \text { follow up visit }\end{array}$ & $\begin{array}{l}\text { Infection - 34\% } \\
\text { Post-partum } \\
\text { hemorrhage - 8\% } \\
\text { Infection - 12\% } \\
\text { Post-partum } \\
\text { hemorrhage - 0\% }\end{array}$ \\
\hline
\end{tabular}

Table-III. Neonatal and maternal outcome and $4(8.0 \%)$ had post-partum haemorrhage. On the second follow-up only $6(12.0 \%)$ patients had still infection but 3 patients were treated for infection. (Table-III)

\section{DISCUSSION}

PPROM constitutes one of the most important dilemmas in current obstetrics practice. Several authors have advised obstetric services to build up their own protocols in regards to management of PPROM, based on the population's specifications and socioeconomic status as well as the level of the health care offered by the hospital. But still the prediction and prevention of PPROM remains a significant challenge in obstetrics. With this in mind we observed the advantages and disadvantages of expectant management after PPROM.

In our study the diagnosis of PPROM was done via speculum examination. Digital examination was avoided until the patient went into labour. This is keeping in favour with multiple studies which advice to avoid digital examination ${ }^{6}$.

Multiparity, previous preterm deliveries and previous PPROM were the most common identifiable risk factors. The Preterm Prediction Study, a large prospective study conducted by the National Institute of Child Health and Human Development MaternalFetal Medicine Units Network, observed that women with a history of PPROM had a $13.5 \%$ rate of PPROM in a subsequent pregnancy compared to $4.1 \%$ in women with no such history ${ }^{7.8}$. However an article by Mercer et al found that preterm birth in previous pregnancy was an insensitive marker for peri-viable birth in the second pregnancy? .

An inverse correlation was noted between latency period in women with PPROM and early gestational age. It was found that $70 \%$ of women were delivered within 48 hours and rest of the women delivered within ten days. This observation is in accordance 
with other studies, one done at DHQ hospital Faisalabad where $78 \%$ cases delivered within 48 hours $^{10}$ also in a meta-analysis which showed higher gestational week at admission was associated with shorter latency interval ${ }^{11,12}$.

In our study 88\% women had normal vaginal deliveries. Indications for caesarean section were development of clinical signs of chorioamnionitis in four cases and foetal distress in two cases in comparison to a study done in Abbottabad where normal vaginal delivery occurred in $65.86 \%$ while and C-section rate was $14 \%{ }^{13}$.

PPROM remains a major cause of preterm delivery, neonatal morbidity and mortality. During my study period, neonatal outcome was improved in our unit as shown by no antepartum mortality. To prevent maternal and neonatal sepsis universal prophylactic antibiotic usage in PPROM in recommended ${ }^{14,15}$. In this study cephradine $500 \mathrm{mg} \mathrm{I/V} 8$ hourly and metronidazole $500 \mathrm{mg} \mathrm{I/V} 8$ hourly were used for 48 hours followed by oral therapy.

Most of the deaths were associated with the complications of extreme prematurity. The greatest risk of pulmonary hypoplasia is observed if PPROM occurs before 30 weeks. That is why in the absence of evidence of intrauterine infection, checked by sign and symptoms of chorioamnionitis and biochemical markers every PPROM is routinely managed conservatively until 36 weeks in order to gain foetal lung maturity. However, contrary to this statement Lieman and his colleagues16 gave the idea that little benefit is gained in terms of improved neonatal mortality and morbidity in prolonging gestation beyond 34 weeks and that delivery should be considered once this gestation has reached. In our study two doses of dexamethasone $12 \mathrm{mg}$ intramuscular 12 hours apart were given to enhance foetal lung maturity. In majority of our hospitals, the NICU facilities are not available to assess for foetal lung maturity, so conservative management despite short latency period was adopted to allow time for antenatal corticosteroids administration and allowing spontaneous labour to decrease the chance of respiratory distress syndrome.

Total $14(28 \%)$ neonates were admitted in NICU. Among them 9(18\%) neonates of oligohydramnios mothers were admitted while 5(10\%) neonates of the mothers with normal AFI were admitted. Several studies have implicated oligohydramnios in patients with preterm premature rupture of membranes as a significant factor for perinatal morbidity and mortality. NICU duration of stay was more in babies who delivered at gestational ages between 28-32 weeks. In a study by Neerhoff et al, it was noted that length of hospital stay was more in babies born at less than 34 weeks of gestation ${ }^{17}$.

The most common neonatal morbidity found in my study was septicemia. While RDS was the commonest complication reported in other studies also in a study done in Amman, Jordan.18 Perinatal mortality was $10 \%$ and $14.7 \%$ in study conducted at Faisalabad ${ }^{10}$. One explanation for this poor outcome may be attributed to overall lack of neonatal intensive unit care facilities, equipment and trained staff. Comparison of neonatal out come in relation to weight of new born showed that most of the babies who did not survive and admitted in NICU had birth weight less than $2 \mathrm{Kg}$ indicating that birth weight affect the neonatal outcome in terms of decreased mortality with increasing birth weight as it was observed in a study done by Hájek et al ${ }^{19}$.

Professor Helmer ${ }^{14}$ in his article wrote that expectant management of PPROM offer better perinatal and long term survival than previously believed. Women with PPROM after 32 weeks should be considered for delivery and after 34 weeks the benefits of elective delivery appear to outweigh the risks. He also concluded that antenatal antibiotics and corticosteroid 
therapy have clear benefits and must be offered to all the women without contraindications .But in our study patients were given expectant management even at 36 weeks because of poor neonatal intensive care facilities in Pakistan as compared to developed countries. As our main objective, was to decrease neonatal mortality and morbidity by prolonging the pregnancy.

Parland and his colleague ${ }^{20}$ in 2004 favor the concept of direct correlation between amniotic fluid and latency period. Lower AFI is associated with greater incidence of infection and a shorter latency period as observed in our study.

\section{CONCLUSIONS}

In conclusion expectant management till 36 weeks is a suitable option as gestational age at delivery and birth weight both affect neonatal survival. It can give time to administer corticosteroids to allow foetal lung maturity and possibly prevent RDS. Our study showed no maternal deaths but foetal deaths occurred due to septicaemia and RDS with direction co-relationship with low birth weight. More facilities are required to monitor for RDS and timely assess lung maturity.

\section{Copyright@ 15 Aug, 2013.}

\section{REFERENCES}

1. Aagaard-Tillery KM, Nuthalapaty FS, Ramsey PS, Ramin KD. Preterm premature rupture of membranes: perspectives surrounding controversies in management. Am J Perinatol. 2005;22:287-97.

2. Menon R, Fortunato SJ, Yu J, Milne GL, Sanchez S, Drobek CO, et al. Cigarette smoke induces oxidative stress and apoptosis in normal term fetal membranes. Placenta. 2011;32:317-22.

3. Guo Y, Tan H, Zhou S, Luo M, Wang S, Cai C, et al. [A population based study on incidence and determinants of preterm birth in Liuyang Hunan]. Zhong Nan Da Xue Xue Bao Yi Xue Ban. 2013;38:4138.
4. ACOG Committee on Practice Bulletins-Obstetrics. ACOG Practice Bulletin No. 80: premature rupture of membranes. Clinical management guidelines for obstetrician-gynecologists. Obstet Gynecol. 2007; 109:1007-19.

5. Kenyon SL, Taylor DJ, Tarnow-Mordi W; ORACLE Collaborative Group. Broad-spectrum antibiotics for preterm, prelabour rupture of fetal membranes: the ORACLE I randomised trial. ORACLE Collaborative Group. Lancet. 2001; 357:979-88.

6. Canavan TP, Simhan HN, Caritis S. An evidencebased approach to the evaluation and treatment of premature rupture of membranes: Part II. Obstet Gynecol Surv. 2008; 59:678-89.

7. Mercer BM, Goldenberg RL, Moawad AH, Meis PJ, lams JD, Das AF, et al. The preterm prediction study: effect of gestational age and cause of preterm birth on subsequent obstetric outcome. National Institute of Child Health and Human Development MaternalFetal Medicine Units Network. Am J Obstet Gynecol 1999; 181:1216-21.

8. Noor S, Fawwad A, Shahzad H, Sultana R, Bashir R. Foetomaternal outcome in patients with or without premature rupture of membranes. J Ayub Med Coll Abbottabad. 2010; 22:164-7.

9. Mercer B, Milluzzi B, Collin M. Periviable birth at 2026 wks of gestation. Proximate causes previous obstetric history and recurrence risk. Am J Obstet Gynecol 2005; 193: 1175-80.

10. Tahir S, Aleem M, Aziz R. Incidence and outcome of preterm premature rupture of membranes. Pak $\mathrm{J}$ Med Sci. 2002; 18: 26-32.

11. Dagklis T, Petousis S, Margioula-Siarkou C, Mavromatidis G, Kalogiannidis I, Prapas N,et al. Parameters affecting latency period in PPROM cases: a 10-year experience of a single institution. J Matern Fetal Neonatal Med. 2013 Apr 19.

12. Test G, Levy A, Wiznitzer A, Mazor M, Holcberg G, Zlotnik $A$, et al. Factors affecting the latency period in patients with preterm premature rupture of membranes. Arch Gynecol Obstet. 2011; 283:70710. 
13. Noor S, Nazar AF, Bashir R, Sultana R. Prevalence of PPROM and its outcome. J Ayub Med Coll Abbottabad. 2007; 19:14-7.

14. Helmer $H$. Continuing challenges in treating preterm labour: preterm prelabour rupture of the membranes BJOG 2006; 113:111-2.

15. Phupong V, Kulmala L. Clinical course of preterm prelabor rupture of membranes in the era of prophylactic antibiotics. BMC Res Notes. 2012; 5:515.

16. Leiman JM, Brumfield Cg, Carlo W, Ramsey PS. Premature rupture of membranes: Is there an optimal gestational age for delivery? Obstet Gynecol 2005; 105: 12-17.
17. Neerhof MG, Cravello C, Haney El, Silver RK. Timing of labor induction after premature rupture of membranes between 32 and 36 weeks' gestation. Am J Obstet Gynecol .1999; 180: 349-52.

18. Al-Qa'Qa K, Al Awaysheh F. Neonatal outcome and prenatal antibiotic treatment in premature rupture of membranes. Pak J Med Sci. 2005; 21:441-4.

19. Hájek Z, Horáková V, Koucký M, Dokoupilová M, Plavka R, Pařízek A. [Acute or expectant management in premature labour with preterm premature rupture of the membranes?]. Ceska Gynekol. 2012; 77:341-6.

20. Parland PM, Jones G, Taylor D. Preterm labour and prematurity. Current Obstet \& Gynecol 2004;14: 309-19.

\section{AUTHOR(S):}

1. DR. SAADIA YASIR, FCPS

Assistant Professor of Gynae. \& Obst

Mohiuddin Islamic University

Mirpur Azad Kashmir

2. DR. BUSHRA KANT, FCPS

Assistant Professor of Gynae. \& Obst

Mohiuddin Islamic University

Mirpur Azad Kashmir

3. DR. TAHIRA JABBAR

Professor of Gynae. \& Obst.

Mohiuddin Islamic University

Mirpur Azad Kashmir

\section{Correspondence Address:}

Dr. Saadia Yasir

Flat No. 45/3 Barral Colony

Mangla Cantt.

yasir_mto@yahoo.com

\section{PREVIOUS RELATED STUDIES}

Nazia Amjad, Tayyaba Imran, Ahsen Nazir Ahmed. FETOMATERNAL OUTCOME OF PREGNANCY BETWEEN 40 AND 42 WEEKS (Original) Prof Med Jour 15(3) 317-322 Jul, Aug, Sep, 2008. 